\title{
6. 特殊環境撮像技術
}

一原子力発電所における撮像技術一

\section{木 村 元比古 ${ }^{\dagger}$}

\section{1. ま え がき}

日本では昭和 41 年に本格的に原子力による発電を 開始して以来 29 年を経て, 1995 年末現在 50 基の原 子力発電所が稼働中であり, 電力需要の約 $30 \%$ をま かなうに至っている. 基幹電力として重要な位置を占 めており, 安全にかつ安定的に運転を継続することは 社会的にも重要な課題である.

\section{1 原子力発電所の概要}

日本で発電を行っている原子力発電所には大きく分 けて, 沸騰水型原子炉 (Boiling Water Reactor: BWR）と加圧水型原子炉（Pressurized Water Reactor: PWR) の 2 種類がある. 双方とも $\mathrm{U}^{235}$ の核分 裂によって発生した熱により水(軽水)を蒸気に変え, 高圧の蒸気によりタービン発電機を回して電気を作り
出すため軽水炉と呼ばれている。図 1 に当社が製作し ている BWR の概念図を示す。原子炉建屋と夕ービ ン建屋から構成されている．原子炉建屋の中心部には 原子燃料を内蔵する圧力容器が設置されており, この 中で蒸気を発生している. 圧力容器の外側には格納容 器が設置され, 万が一の場合にも放射能が漏洩しない ように保護している。この中には炉内の水を循環する ためのポンプやバルブ等の重要部品が設置されてい る. 原子炉建屋は複数階で構成され, 各階には原子炉 に必要なポンプ, バルブ, 熱交換器, 制御盤等が設置 されている.タービン建屋にはタービン発電機, 復水 器等が設置されている. 原子炉の運転は, 中央操作室 から遠隔で行われるため, 運転に必要なスイッチ, 計 器, 警報が集中して設置されている。当直長が運転の 責任を負っており, 情報が集中するようになってい

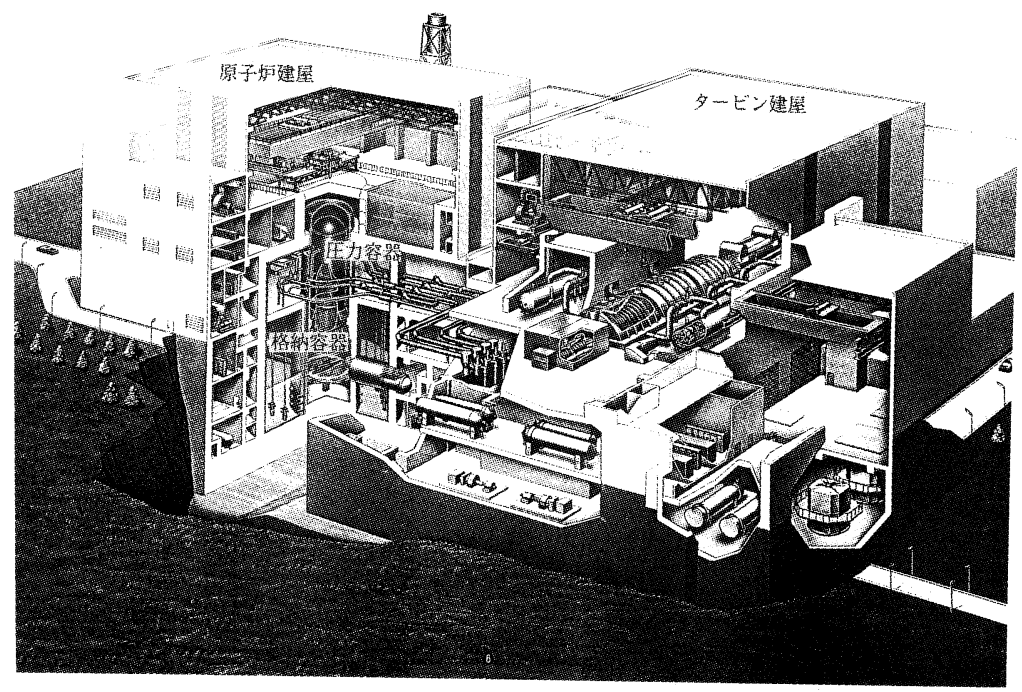

†株式会社東芝 原子力技術研究所

図 1 BWR の概念図

"Image Pickar Technologies for Special Environment;

Nuclear Power Station" by Motohico Kimura (Nuclear

Power laboratories, Toshiba Corp., Yokohama) 
る。

\section{2 原子力発電所の環境条件}

原子力発電所が火力発電所等のプラントと大きく異 なる点は, 放射線の存在と, 定期点検時の水中作業で ある。また BWR では運転中は格納容器内は窒素雾 囲気に置換され，作業員が近づけないことも異なる点 である。

その他の原子炉建屋やタービン建屋内は，一部に高 温や放射線の強い場所もあるが，環境条件は一般のプ ラントとそう変わりはなく, 常温, 常湿度, 常圧であ る.

原子力発電所に特異の放射線環境は, 場所毎に大き く異なっている．放射線には $\alpha$ 線， $\beta$ 線， $\gamma$ 線，中性 子線があるが, 主に問題となるのは $\gamma$ 線である。作 業員に対する放射線管理上は放射線の強さ $1,2,3$ の 3 段階に区分され，污染の度合を表す $\mathrm{A}$ (なし)，B (可能性あり), $\mathrm{C}$ (低レベル), $\mathrm{D}$ (中以上) と合わせて $1 \mathrm{~A}$ 区域, $2 \mathrm{~B}$ 区域, $3 \mathrm{~A}$ 区域のように表される。放 射線の強さ 1 は $0.1 \mathrm{mSv} / \mathrm{h}$ 以下, 2 は $0.1 \sim 1 \mathrm{mSv} /$ $\mathrm{h}, 3$ は $1 \mathrm{mSv} / \mathrm{h}$ 以上である.ここで $\mathrm{Sv}$ (シーベル ト）とは線量当量と呼ばれる単位で，人体に対する影 響を考慮した放射線の量であり，放射線施設で從事す る作業員に対して法律で年間の線量当量限度 $50 \mathrm{mSv}$ と定められている。電力会社ではさらに低い値を管理 值として定めて, 運営している. 機器に対する影響は $\mathrm{Gy}$ (グレイ)で表される. $\mathrm{Sv}=\mathrm{Gy}$ と考えてよいので 1 $\mathrm{mSv} / \mathrm{h}$ の場所に 100 時間置かれた機器は $100 \mathrm{mGy} の$ 放射線を受けたことになる。人体の全身被ばくによる 影響は，1回に 50〜 $150 \mathrm{mSv}$ ではほとんど無症状で あるが, 4000〜 6000 mSvでは重症となり，6〜14 Sv で死亡する ${ }^{1)}$. 機器部品に関しては, 劣化や故障等の 影響があるが, 弱いものでも $100 \mathrm{~Gy}$, 強いものは $10^{6}$ Gy 以上の耐放射線性能を持つ。もちろん放射線の強 い場所は, 遮蔽, 距離, 時間を考慮し作業に支障がな いよう対策がとられている。

放射線の最も強い場所は, 燃料集合体および炉心を 形成する炉内構造物周辺である. 燃料集合体は $\mathrm{U}^{235}$ の核分裂によってできた核分裂生成物を内包するため に，また，炉内構造物は運転中の中性子により成分金 属が放射化し半減期の長い放射性元素になるために, 放射線が強くなっている。この近辺の放射線は $10^{3}$ $\sim 10^{5} \mathrm{~Gy} / \mathrm{h}$ 位となっているが, 通常水中に没してい るので作業員にはほとんど影響しない。次に放射線の 強いのは炉水中の放射性物質が付着する, タービン系 を含む 1 次系配管, 機器の周辺であるが, 炉心に比較 すると析違いに少なく, 高くても数 $\mathrm{mGy} / \mathrm{h}$ 以下の場
所が多い.

温度については, 格納容器内を除けば局所的に高い 場所もあるが, 一般的には常温である。格納容器内は 運転中は密閉され窒素雾囲気となっているが，ローカ ルクーラが設置されているので, $40^{\circ} \mathrm{C}$ 前後になってい る. 炉水は運転中は $285^{\circ} \mathrm{C}, 700 \mathrm{MPa}$ であるが, 定検

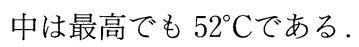

\section{2. 原子力発電所における撮像機器}

前章に述べた環境条件で使用されている，または望 まれている撮像機器について述べる.

\section{1 用 途}

原子力発電所で使用されている撮像機器の用途は, 主に監視点検および点検・検査である．監視点検は主 に運転中の機器の状態や, 健全性の確認のために行わ れる. 固定式カメラや, 移動式監視装置が用いられ る. 点検・検査に用いられる撮像機器は, 作業員の近 づけない環境下で目視点検・検査を行うものが多く, 原子炉内では水中で使用できるテレビカメラが用いら れる。炉心から燃料貯蔵プールに移された燃料の検査 や, 炉内構造物の検査に必要であるとともに, 炉内で の遠隔作業の支援装置として使用されることも多い.

\section{2 要求仕様}

上記の用途に使用される撮像機器には解像度や最低 照度のほか, 以下の条件が要求される。

(1) 監視点検用としては耐放射線を含めて少なくと も 1 年間の連続使用に耐えられること. 特に格納 容器内に設置される機器は故障時に作業員が接近 できないため, 高い信頼性を持つこと.

(2) 移動式監視装置用の撮像機器は小型軽量である こと.

(3) 点検・検査用には特に耐放射線性が重要で, $10^{3} \mathrm{~Gy} / \mathrm{h}$ 程度の放射線環境下で良好な映像が得 られること, $100 \mathrm{~h}$ 程度の寿命があること．

(4) 点検・検査用は, 水密容器に収納し炉内構造物 の狭隥部で使用するため, 小型軽量であること. $52^{\circ} \mathrm{C}$ の水中で使用可能なこと.

このほかにも，メンテナンスが容易であることや， 原子力といえどもコストダウンが重要視される.

\section{3. 原子力発電所における撮像機器の使用例}

以下に, 原子力発電所で使用されている撮像機器の 例を, 点検監視と点検・検査について紹介する。

\section{1 モノレール式監視装置 ${ }^{233}$}

(1) 目 的

原子力発電所で通常運転時に運転員によって機器の 
監視作業が行われているが, 線量の高いエリアもあ り, 被ばくの問題がある.また, 放射線の強い場所で は監視点検時間が制限されるため, 充分な点検が行わ れない恐れがある。また，運転中の BWR プラント で運転員が立入れない場所の監視の要求も出てきてい る.これらのエリアには運転上重要な機器が設置され ており, 異常発生に対しては少しでも早く検知するこ とが望まれる. 運転員の監視点検作業は人間の五感に よって行われるが, 表 1 の原子力発電所の監視点検方 法についての分析結果 ${ }^{4)}$ が示すように，ほぼ70\%は 視覚情報によっている.このため運転員の代替には撮 像機器が重要である.

表 1 原子力発電所の監視点検方法

\begin{tabular}{|c|c|c|c|}
\hline 点検項目 & 割合(\%) & \multicolumn{2}{|c|}{ 方法別割合 (\%) } \\
\hline $\begin{array}{l}\text { スイッチ等の位置 } \\
\text { 液位 } \\
\text { メータ針読取 } \\
\text { 数値読取 } \\
\text { 弁・配管等の漏洩 } \\
\text { 弁開閉 } \\
\text { 配管・内容等の腐食 } \\
\text { ドア・ダンパの状態 } \\
\text { ボンベの数 } \\
\text { 機器等からの煙 } \\
\text { 機器等の破損・変形 } \\
\text { 特定物の状態変化 } \\
\text { 表示等・ランプの状態 }\end{array}$ & $\begin{array}{r}4.9 \\
6.6 \\
16.6 \\
0.2 \\
15.0 \\
9.4 \\
0.6 \\
1.4 \\
0.05 \\
0.05 \\
1.2 \\
5.4 \\
6.9 \\
\end{array}$ & 視覚 & 68.3 \\
\hline 異音 & 11.1 & 音 & 11.1 \\
\hline 異臭 & 6.0 & 臭 & 6.0 \\
\hline $\begin{array}{l}\text { 触手による異常振動 } \\
\text { 視覚による異常振動 }\end{array}$ & $\begin{array}{l}8.0 \\
0.2\end{array}$ & 振動 & 8.2 \\
\hline 温度異常 & 4.7 & 温度 & 4.7 \\
\hline テスト動作 & 1.7 & 操作 & 1.7 \\
\hline \multicolumn{4}{|c|}{$\begin{array}{lc}\text { 総点検機器数 } & 1818 \text { 台 } \\
\text { 総点検箇所数 } & \text { 約 } 6000 \text { 力所 }\end{array}$} \\
\hline
\end{tabular}

\section{（2）監視点検方式}

監視点検は, 定点にカメラを設置する固定計装方式 と, カメラを移動機構に搭載して移動しながら監視す る移動計装方式に分けることができるが, 監視点検対 象が固定されておらず，広範囲の監視点検を行うには 移動点検が行われる. 移動方式にも点検員と同様に床 面を移動する点検車にカメラを搭載して巡回する方 法5) と, あらかじめ軌道を設置し, 軌道上をカメラを 搭載した点検車が走行しながら監視点検する方法があ る. 両方の技術開発が行われているが，現状のロボッ 卜技術レベル, 信頼性, 安全性の面から, 軌道方式で あるモノレール式監視点検装置が実用化の段階であ る. 以下に格納容器に設置された監視装置について述 ベる.

（a） システム構成システムは，図２に示すよ うに, 格納容器内に設置した軌道上走行する, センサとしてズームレンズ付テレビカメラを搭 載した視覚系監視装置本体（図 3)，センサと して赤外線カメラ, マイクロホン, およびテレ ビカメラを搭載した音・温度系監視装置本体, 操作盤 (制御用, 画像処理用計算機), 電源お よび変復調器からなる現場盤から構成される. 軌道は格納容器内でループ状に全長 $82 \mathrm{~m}$ 設

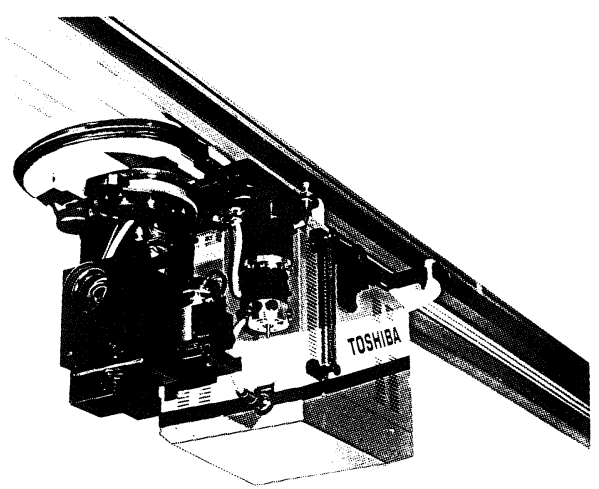

図 3 視覚系監視装置

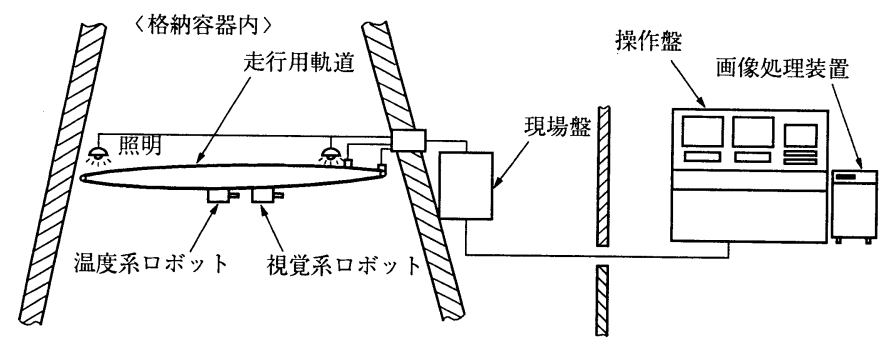

図 2 格納容器内監視装置システム構成 
置し, 1 台が故障した場合には他の 1 台で点検 できるように，呪長性を持たせている，格納容 器内は運転中は窒素ガスに置換されており, 作 業員が入れないため部品交換できないので, 監 視装置の機器は, 約 1 年間にわたり放射線を受 けることになるが, CCD カメラの寿命に近い 線量を受けるので, 点検時以外は鉛の遮蔽をし た待機場所に停止している方法で被ばく量を低 減している．部品毎に交換の周期を定め定期点 検時にメンテナンスを行っている.

(b) 点検対象格納容器内での点検対象は主に 動的機器である再循環ポンプ, 主蒸気隔離弁, およびローカルクーラである，点検対象と点検 項目を表 2 に示す.

(3) 視覚系監視装置

（a） システム本監視装置では, 操作室にある ホストコンピュータと軌道に敷設した 2 本のト ロリー線を介してシリアルデー夕通信を行うと ともに, 同線に画像デー夕, 音声デー夕を重ね た多重通信を行っている，監視装置本体はホス トコンピュータからの指令データ(目標座標, 走行速度など)を受信し, ロボットの状態デー 夕(走行位置, 雲台姿勢など)をホストコンピュ ータへ送信して, 自動的に移動を行う.

表 2 格納容器内点検対象と点検項目

\begin{tabular}{c|l|c|c|c|}
\hline \hline \multirow{2}{*}{ 対象機器 } & \multicolumn{1}{|c|}{ 点 検 項 目 } & \multicolumn{3}{|c}{ 点検方法 } \\
\cline { 3 - 6 } & \multicolumn{2}{|c|}{ 画像 } & 温度 & 音 \\
\hline 再循環ポンプ & 配管からの水の漏洩 & $\bigcirc$ & & \\
\cline { 2 - 6 } & メカシール部の漏洩 & $\bigcirc$ & $\bigcirc$ & \\
\cline { 2 - 6 } & モータ油面計レベル & $\bigcirc$ & & \\
\cline { 2 - 6 } & 異音(モータ軸受異常, 芯ずれ等) & & & $\bigcirc$ \\
\hline 主蒸気隔離弁 & グランド部の漏洩 & $\bigcirc$ & $\bigcirc$ & \\
\cline { 2 - 6 } & フランジ部の漏洩 & $\bigcirc$ & $\bigcirc$ & \\
\hline & 異音(付属配管振動等) & & & $\bigcirc$ \\
\hline
\end{tabular}

表 3 監視装置の仕様

\begin{tabular}{c|l}
\hline \hline 搭載センサ & 8 倍ズーム付きカラーテレビカメラ, マイクロホン \\
\hline 走行方式 & 自走式 \\
\hline 走行速度 & $4 \mathrm{~m} /$ 分（定格） \\
\hline 雲台動作範囲 & $\begin{array}{l}\text { 左右 } 135^{\circ} \\
\end{array}$ \\
\hline 上 $30^{\circ}$, 下 $90^{\circ}$ \\
\hline 寸 法 & W $280 \times \mathrm{H} 260 \times \mathrm{L} 560 \mathrm{~mm}$ \\
\hline 重 量 & 約 $12 \mathrm{~kg}$ \\
\hline
\end{tabular}

（b）点検機能監視装置の仕様を表 3 に示す. 軌道の配置上点検対象に接近することに制約が あるため, センサとして 8 倍のズームレンズ付 き $\mathrm{CCD}$ テレビカメラを搭載し, 接近できない 分をカバーしている. 格納容器内は狭险である ため, 通過断面積の制限から照明は外部照明と して点検に必要な照度を確保している。運転操 作は操作盤からの指令により動作する 1 台を選 択した後, 全自動または手動で点検を行うこと が可能である。得られた画像は, 画像処理用の 計算機により処理を行い, 蒸気の漏洩, 水滴落 下等の異常を自動的に検出することが可能であ る.

\section{2 水中点検ロボット}

\section{(1) 目的}

定期検査時には圧力容器内の溶接部の検査や, 炉内 機器の取外し, 取付け, 交換作業が行われるが, これ らの作業は水中遠隔作業となる. 図 4 にBWRの断 面図を示す。作業は装置を原子炉上部のフロアに設置 された燃料交換機のホイストで吊り下げたり，作業員 が吊り下げたりして行われる。検查や装置の据えつけ 作業の補助として撮像機器が必要であるが, 現在は主 に水密構造としたテレビカメラが使用される．放射線 の強い場所では特に耐放射線を考慮した撮像管方式の

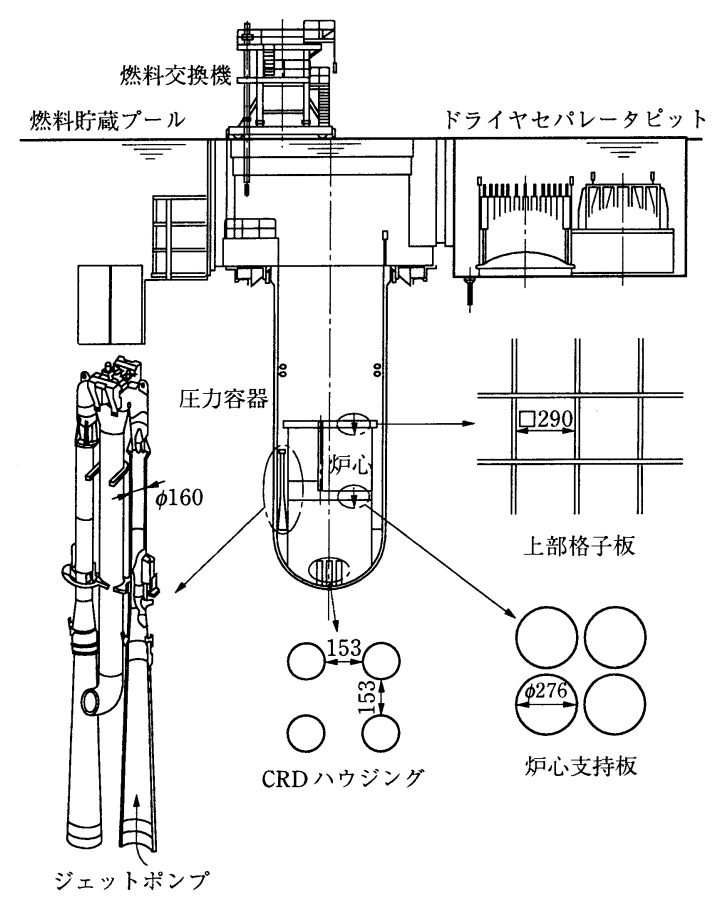

図 4 BWR の断面図 
水中テレビカメラが使用される．世界中で数社が製品 化しており，積算線量 $10^{6} \mathrm{~Gy}$ 程度の耐放射線性能を 持つが，大型で価格も数 100 万円と高価である. 寿命

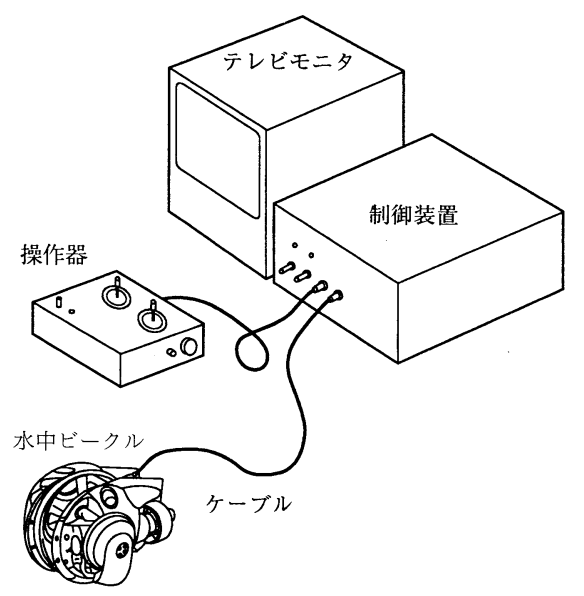

図 5 システムの構成

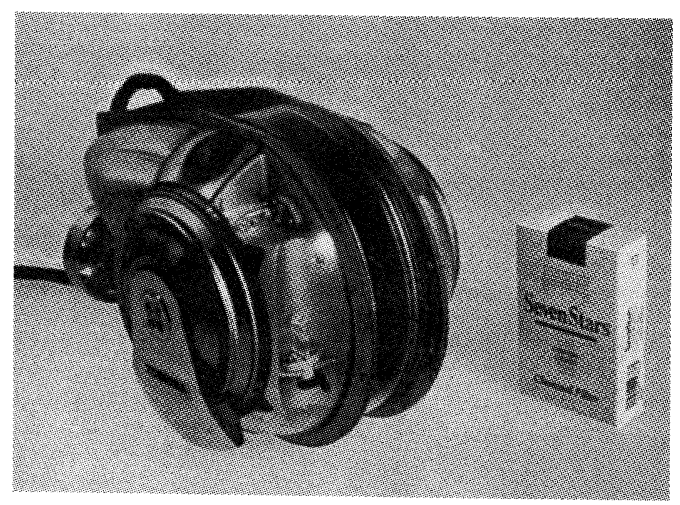

写真 1 水中ビークル

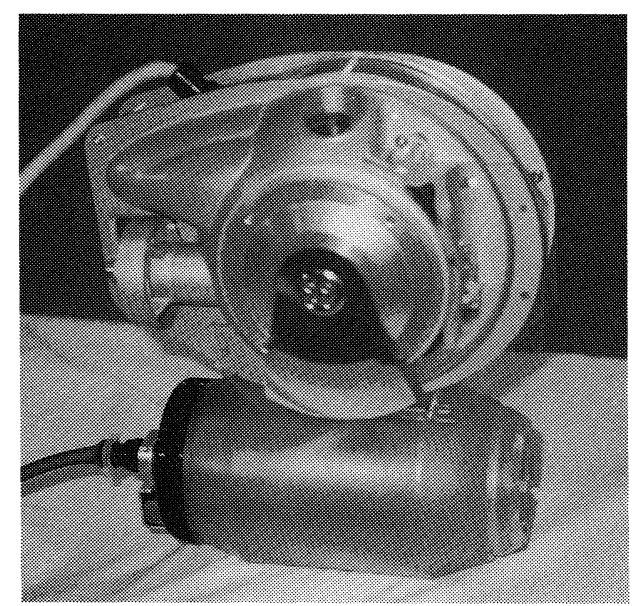

写真 2 耐放射線白黒撮像管式テレビカメラ
は短いが CCD カメラを水密容器に入れた水中カメラ も使用される。積算線量 $10^{2} \mathrm{~Gy}$ 程度の寿命であるが, 安価で鮮明なカラー画像が得られる。これらの水中カ メラは吊り下げて使用するためペンダント式と呼ばれ ている.ペンダント式は構造物の陰や, 複雑形状の構 造物が設置されているような環境では使用できないの で, 水中を自走し炉内の隅々まで移動可能な点検口ボ ツトが開発され使用されている ${ }^{6)}$.

(2) システム構成

図 5 にシステムの構成を示す。テレビカメラを搭載 し水中を移動する水中ビークル, 制御装置, 操作器お よびケーブルから構成される. 写真 1 に世界最小・最 軽量の水中ビークルを示す。中央部に $\pm 90^{\circ}$ 首振り機 構に取付けられた CCD カメラがあり, その両側には 6 個のハロゲンランプが取付けられている。本体は水 密構造となっており, 浮力と重力を水中でバランスさ せているので水中に止まっていることができる。ケー ブルも中性浮力とし運動を妨げないようにした。水平 方向に 2 個, 垂直方向に 2 個の推進機を持っており, これらの推進機によって前進, 後退, 旋回, 浮上, 潜 行が可能である。このほかに左右につけたバランサを 回転することによって, 本体の向きを上下に変えるこ とができる。

本装置の開発は写真 1 に示すように, BWR 圧力容 器の中でどこにでも適用可能なように小型化を目的と した。 そこで耐放射線性能は落ちるが，カメラには CCD カラーカメラを採用し, 炉内の隅々まで移動可 能となった。

また放射線の強い場所への適用も考慮して, 写真 2 に示すように本体に取付け可能な耐放射線白黒撮像管 式テレビカメラを開発した。柔軟中性浮力ケーブルを 採用し, 水中ビークルの運動性能を妨げないようにし た。

\section{4. 課題と将来への展望}

以上述べたように, 原子力発電所での撮像機器の要 求は大きく分けて, 監視点検と点検・検査があるが, 現在最も世の中で一般的に使用され, 価格も安い CCD カメラが放射線に弱く, 最もニーズの高い場所 で使用できない, または寿命が短いという問題があ る.放射線に強いCCD カメラまたはそれに代る高性 能, 小型で安価な撮像機器の開発が待たれるところで ある。しかしながら，技術の可能性と開発費の大きさ が, 原子力という狭い市場では整合しないため, 積極 的に耐放射線 CCD カメラを開発するのは難しい。一 般産業の技術の進展が耐放射線に良い影響与える結果 
となった時に，その技術を原子力に適用することが現 実的と考える. 半導体技術の進展により酸化シリコン の厚さが薄くなることは，耐放射線には良い影響を及 济すという報告もある7ので，今後 CCD カメラの耐 放射線性が向上することが期待できる。また，マイク 口技術の進歩による真空素子の研究も成されているよ うであり, 今後, 撮像機器として世の中に出現するこ とを期待するところである。

\section{5.むす び}

原子力発電所の撮像機器について紹介した.

我々のニーズを理解していただき，少しでも放射線 に強い撮像機器の開発が進展することを期待する.

当学会にとってはかなり異分野の話であるので, 読 まれる方にとっては理解しずらい面も多いかと思う が, 少しでも原子力発電所における撮像機器について 理解を深めるのにお役に立てれば幸いである.

(1996 年 10 月 15 日受付)

\section{〔参 考 文 献〕}

1）伊澤ほか：“放射線の防護 改訂三版”, p. 161, 丸善（1978）

2）木村, 中山, 岡野, 伊藤：“原子力用点検ロボットの開発”, 第
3 回ロボティクス・自動化システムシンポジウム, 計測自動 制御学会 (1991)

3）木村, 渡辺, 大塚：“原子力プラント用移動点検ロボット”, 東 芝レビュー, 46, 7, pp. 534-537 (1991)

4）山本：“原子力発電所用運転・保守作業ロボット”, 火力原子 力発電, 41,11, p. 54 (1990)

5) Y. Hattori, M. Sato, S. Kanemoto, I. Tai, H. Okano, H. Shimada: "Application of Remote Sensing Technology to Equipment Condition Monitorring in Nuclear Power Plants", 9th Power Plant Dynamics, Control \& Testing Symposium, pp. 90. 01-90. 13 (1995) Knoxville, TN

6) M. Kimura, et al. : "Compact Visual Inspection Submersible for NPPs", Proceedings of ANS Topical Meeting on Robotics \& Remote Systems, Monterey CA, p. 25, (Feb. 1995)

7) A. Holmes-Siedle, et al.: "The Management of Radiation-Induced Faults in Teleoperators Used in Nuclear Plants", Proceedings of ANS Topical Meeting on Robotics: Remote Systems, Monterey CA (Feb. 1995) ; Proceedings of ANS Topical Meeting on Robotics \& Remote Systems, pp. 169-176, Monterey CA (Feb. 1995)

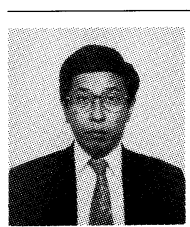

羑柠热比吉 1972 年, 東京都立大学工 学部機械工学科卒業. 同年, (株) 東芝に入 社. 原子力発電所用遠隔自動機器, ロボット の開発に従事. 現在, 原子力技術研究所に所 属. 